\title{
Klasifikasi Gender Berdasarkan Suara Menggunakan Support Vector Machine
}

\author{
Raditya Budi Handoko ${ }^{1}$, Suyanto ${ }^{2}$ \\ School of Computing, Telkom University \\ Jl. Telekomunikasi Terusan Buah Batu, Bandung, West Java 40257, Indonesia \\ ${ }^{1}$ radityabh@students.telkomuniversity.ac.id, ${ }^{2}$ suyanto@telkomuniversity.ac.id
}

\begin{abstract}
A speech gender classification is important in speech recognition and many other applications. The researchers have proposed some methods to develop it, but it is commonly poor for noised speech. In this research, a speech gender classification system is developed and tested for some noise levels. The system contains two steps. First, a feature vector is generated using MelFrequency Cepstral Coefficient (MFCC). The feature vector is then classified using Support Vector Machine (SVM). Five-fold cross-validating on 2,264 utterances, which are equally split into two classes: "male" and "female", shows that the highest accuracy of $100 \%$ is achieved using SVM with Polynomial kernel and degree 1 for clean-speech. The system is robust, where the accuracy slightly decrease to $95.21 \%$, for low noised speech of $-25 \mathrm{~dB}$. But, the accuracy decreases significantly for higher noised speeches.
\end{abstract}

Keywords: speech gender classification, speech recognition, Mel-Frequency Cepstral Coeficient, Support Vector Machine.

\begin{abstract}
Abstrak
Klasifikasi gender berdasarkan suara sangat penting dalam sistem pengenalan suara dan beragam aplikasi lainnya. Para peneliti telah mengusulkan sejumlah metode untuk membangun sistem tersebut, namun umumnya kurang akurat untuk suara berderau. Pada penelitian ini, sebuah sistem klasifikasi gender berdasarkan suara dibangun dan diuji untuk sejumlah tingkat derau. Sistem ini berisi dua langkah. Pertama, vektor ciri dibangkitkan menggunakan $\mathrm{Mel}$ Frequency Cepstral Coefficient (MFCC). Selanjutnya, vektor ciri tersebut diklasifikasi menggunakan Support Vector Machine (SVM). Pengujian menggunakan 5-fold cross-validation terhadap 2,264 suara, yang terbagi secara merata ke dalam dua kelas: "laki-laki" and "perempuan", menunjukkan bahwa akurasi tertinggi 100\% dicapai menggunakan SVM dengan kernel Polynomial dan degree 1 untuk suara bersih. Sistem ini cukup tahan, di mana akurasi sedikit menurun menjadi $95,21 \%$, untuk suara berderau rendah $-25 \mathrm{~dB}$. Tetapi, akurasinya menurun drastis untuk suara berderau lebih tinggi.
\end{abstract}

Kata Kunci: klasifikasi gender, pengenalan suara, Mel-Frequency Cepstral Coefficient, Support Vector Machine.

\section{INTRODUCTION}

$\mathbf{P}$ ENGENALAN suara adalah salah satu bidang riset penting yang saat ini banyak digunakan secara luas untuk beragam aplikasi, seperti sistem keamanan, autentifikasi, interaksi manusia-komputer, analisis fisiologi atau psikologi, dan sebagainya [7]. Untuk digunakan secara praktis, pengenalan suara harus memiliki performansi tinggi. Terdapat banyak cara untuk meningkatkan performansi pengenalan suara, salah satunya adalah dengan menambahkan suatu prosedur klasifikai gender. Dengan adanya klasifikasi gender, ruang masalah dalam pengenalan suara dapat dibatasi hanya berdasarkan gender yang telah diklasifikasikan [2]. Klasifikasi gender dilakukan terhadap dua kelas: laki-laki dan perempuan. 
Raditya B. HANDOKO ET.AL.

Suara yang dihasilkan laki-laki dan perempuan memiliki perbedaan yang cukup jelas berdasarkan bentuk tenggorokannya [6]. Perbedaan suara tersebut dapat diketahui menggunakan teknik pengolahan sinyal suara yang tepat. Banyak metode telah diusulkan untuk membangun sistem klasifikasi gender berbasis suara yang berkaurasi tinggi, namun umumnya masih kurang tahan terhadap derau atau noise.

Penelitian ini fokus pada pembangunan sistem klasifikasi gender berdasarkan sinyal suara dan menguji ketahanannya terhadap noise. Sistem terdiri atas dua bagian, ekstrasi fitur dan klasifikasi. Ekstraksi fitur dilakukan menggunakan MFCC, yang secara umum memiliki akurasi tinggi dibanding metode lain [11]. Sementara itu, klasifikasi menggunakan SVM yang secara empiris terbukti memiliki akurasi lebih tinggi dibanding berbagai metode lainnya [1].

Selanjutnya, Bab II pada makalah ini akan membahas berbagai studi terkait mengenai klasifikasi gender berdasarkan suara. Bab III menjelaskan desain sistem klasifikasi gender. Pada Bab IV akan dibahas hasil eksperimen dan analisis hasil sistem klasifikasi gender. Terakhir, pada Bab V disampaikan kesimpulan dan saran untuk penelitian selanjutnya.

\section{LITERATURE REVIEW}

Klasifikasi gender berdasarkan suara merupakan salah satu dari sejumlah teknik yang menggunakan ciri biometrik tidak terlihat [7]. Banyak peneliti telah mengusulkan sejumlah metode untuk ekstraksi fitur suara dan metode klasifikasi. Pada umumnya, metode ekstraksi fitur yang digunakan adalah MFCC [9] sedangkan metode klasifikasinya adalah SVM [3], [6] karena terbukti sangat efektif dalam klasifikasi dan pengenalan suara [5]. Penelitian yang dilakukan oleh Urmila Shrawankar dan Vilas Thakare [11] menunjukkan bahwa MFCC memberikan akurasi paling tinggi untuk ekstrasi ciri suara dibanding metode lainnya. Pada [1] juga dinyatakan bahwa MFCC adalah metode yang simpel, cepat, dan berakurasi tinggi untuk pengenalan suara.

Secara teknis, MFCC didasarkan pada variasi frekuensi critical bandwidth dari telinga manusia yang digunakan untuk memperoleh fitur suara [4]. Pada [10] dijelaskan bahwa skala Mel-frequency adalah kurang dari $1000 \mathrm{~Hz}$ untuk frekuensi linier sedangkan dan lebih dari $1000 \mathrm{~Hz}$ untuk frekuensi logaritmik. Penghitungan Mel suatu frekuensi dirumuskan sebagai $\operatorname{mel}(f)=2595 \times \log _{10}\left(1+\frac{f}{700}\right)[10]$.

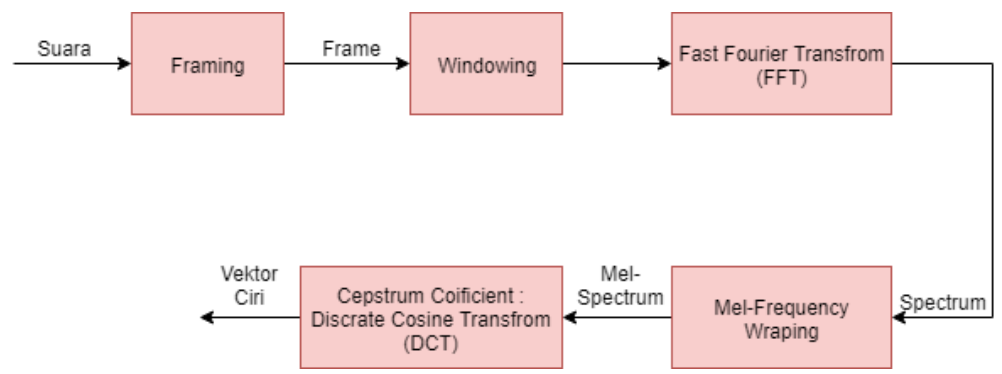

Gambar 1. Blok diagram proses penghitungan MFCC

Gambar 1 menjelaskan diagram blok penghitungan MFCC. Pertama, sinyal suara dipotong untuk menghilangkan keheningan atau gangguan yang mungkin muncul pada awal maupun akhir suara dilakukan framing, membagi ke dalam sejumlah frame [1]. Selanjutnya, proses windowing digunakan untuk meminimalkan diskontinuitas sinyal. Fast Fourier Transform (FFT) kemudian diterapkan untuk mengubah setiap frame ke domain frekuensi. Dalam Mel-frequency wrapping block, sinyal diplot terhadap spektrum Mel untuk meniru pendengaran manusia. Terakhir, Discrete Cosine Transform (DCT) dilakukan untuk menghasilkan vektor ciri.

Berdasarkan riset yang dilakukan Jamil Ahmad dkk. [1], SVM menghasilkan akursi tertinggi di antara metode-metode lain: Naive Bayes (NB), Random Forest (RF), $k$-Nearest Neighbor (kNN), dan Multilayer Preceptron (MLP), untuk berbagai aplikasi telepon. Oleh karena itu, pada penelitian ini SVM digunakan untuk melakukan klasifikasi gender berdasarkan fitur suara berbasis MFCC. 
SVM diperkenalkan oleh Vapnik sebagai model klasifikasi dua kelas (binary classifier). Metode ini menggunakan proses klasifikasi dua langkah. Pertama, sebuah fungsi kernel melakukan transformasi fitur dimensi rendah ke dimensi tinggi. Transformasi ini mentransformasikan data yang non-linearly separable menjadi linearly separable pada dimensi yang lebih tinggi. Terdapat berbagai macam kernel yang bisa digunakan, seperti Polynomial dan Radial Basis Function (RBF). Langkah kedua, dilakukan konstruksi maksimal margin hyperplane untuk menentukan batas keputusan setiap kelas. Konsep separasi maksimum mencegah misclassification of outliers sehingga menjadikan SVM sebagai metode klasifikasi yang berakurasi tinggi [1]. Pada [5] dijelaskan bahwa untuk sebuah himpunan data latih berlabel $T=$ $\left\{\left(x_{b}, l_{i}\right), i=1,2, . . L\right\}$ dengan $x_{i} \in R^{P}$ dan $l_{i} \in\{-1,1\}$, sebuah data uji diklasifikasikan sebagai

$$
f(x)=\operatorname{sign} \sum_{i=1}^{L} \alpha_{i} \cdot l_{i} . K\left(x_{i}, x\right)+b,
$$

di mana $\alpha_{i}$ adalah Lagrange Multipliers, $b$ adalah nilai batas, dan $K$ adalah fungsi kernel. Support vector adalah subhimpunan dari data latih dengan $\alpha_{i}>0$.

\section{RESEARCH METHOD}

Sistem klasifikasi suara berdasarkan gender menggunakan SVM dapat diilustrasikan menggunakan flowchart pada Gambar 2. Sitem ini terdiri atas proses input suara, kemudian dilakukan ekstrasi ciri untuk menghasilkan vektor ciri MFCC. Selanjutnya, proses terbagi menjadi 2, pelatihan dan pengujian. Pada proses pelatihan, dilakukan pemberian label, yaitu -1 untuk gender pria dan +1 untuk gender wanita, sebagai data latih (trainset). Selanjutnya, data ini dilatihkan untuk menghasilkan model SVM. Pada proses uji, vektor ciri akan diklasifikasikan berdasarkan model SVM hasil pelatihan. Terakhir, dilakukan perhitungan akurasi berdasarkan jumlah data yang benar dibagi jumlah seluruh data.

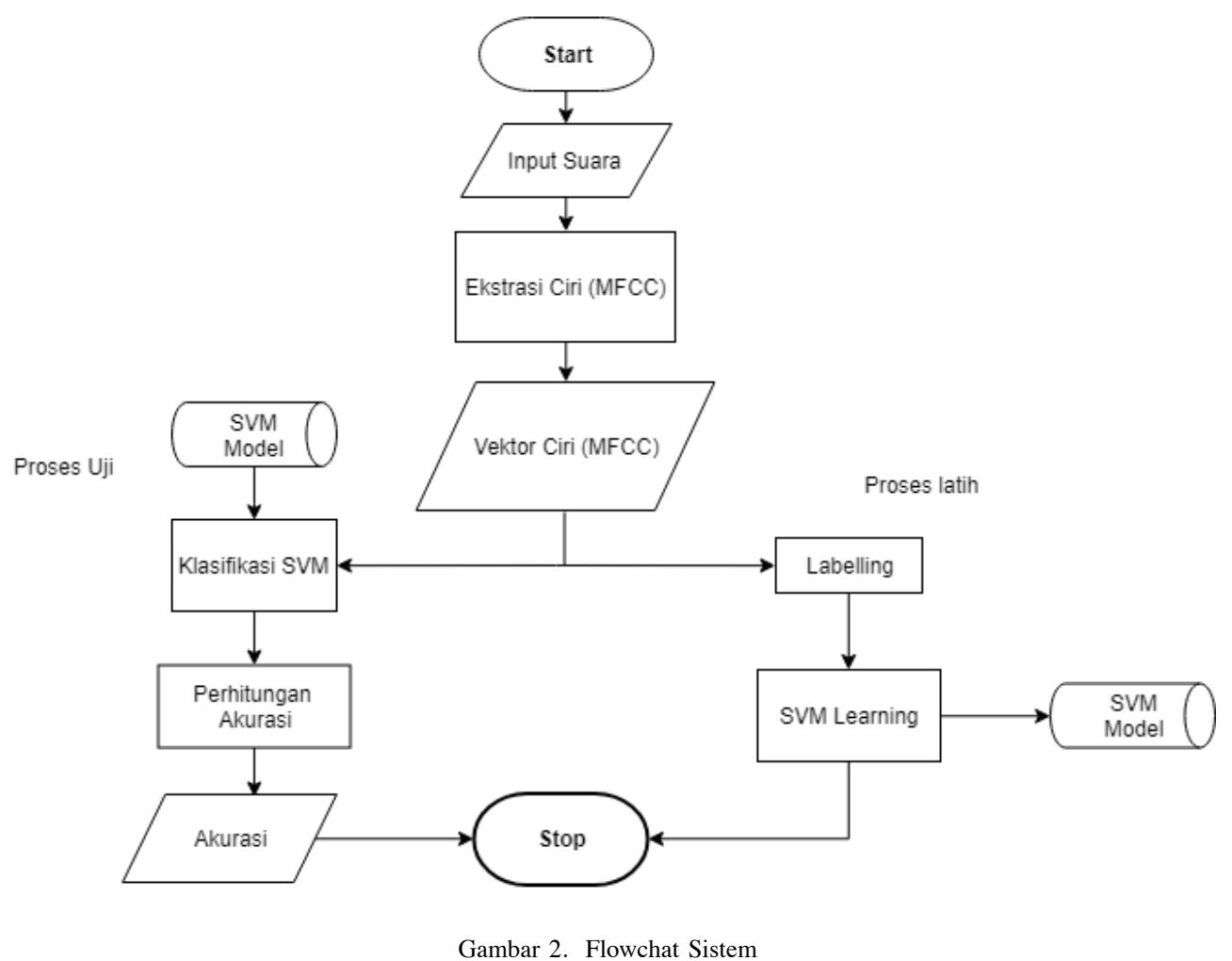

Sementara itu, dataset yang digunakan dalam penelitian ini merupakan rekaman suara berformat .wav, 
Raditya B. Handoko et.al.

yang didapat dari Telecommunications and Signal Processing Laboratory [8]. Penjelasan secara ringkas mengenai dataset tersebut adalah: berisi 2.260 rekaman suara (1.130 suara laki-laki dan 1.130 suara perempuan), di mana rekaman suara berisi pengucapan kalimat yang sama dalam bahasa Inggris.

MFCC terdiri atas sejumlah proses. Pada proses framing, sinyal suara dibagi menjadi beberapa frame, di mana panjang setiap frame yang digunakan pada penelitian ini adalah 25 milidetik dengan overlap 10 milidetik, seperti diilustrasikan pada Gambar 3.

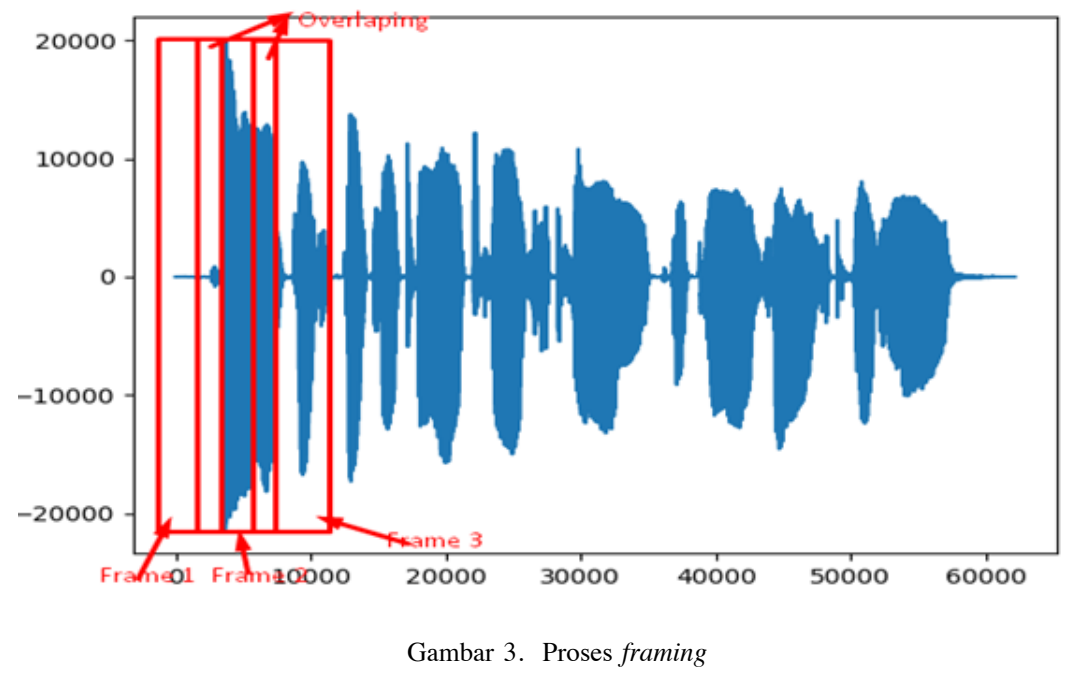

Selanjutnya, proses penjedelaan dilakukan menggunakan hamming window untuk meminimasi efek diskontinuitas dari proses framing. Gambar 4 dan 5 mengilustrasikan hasil dari proses framing dan windowing.

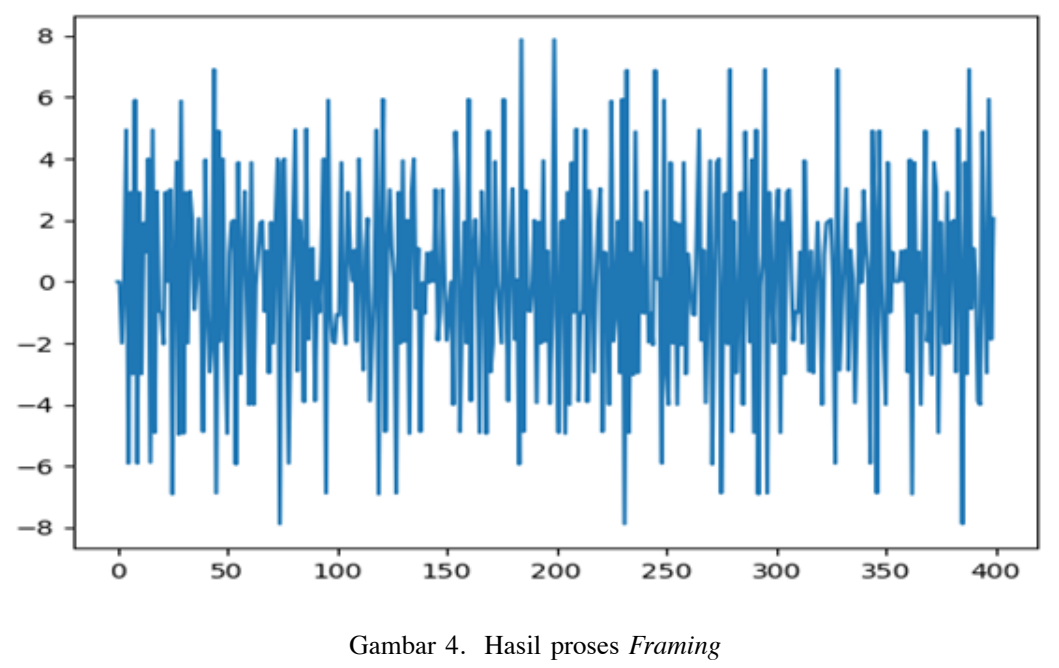

Kemudian, hasil dari windowing tersebut diubah dari domain waktu ke domain frekuensi menggunakan FFT. Pada penelitian ini nilai FFT yang digunakan adalah 256 titik. Keluaran dari proses FFT berupa spectrum magnitude seperti diilustrasikan pada Gambar 6.

Selanjutnya dilakukan proses Mel-frequency wrapping untuk menghasilkan mel-spectrum. Penelitian ini menggunakan filterbank sebanyak 40 filter. Hasil proses tersebut kemudian diubah menjadi cepstrum menggunakan DCT dengan 12 koefisien dan diambil 10 frame dari setiap data. Hasil ekstrasi ciri diilustrasikan pada Gambar 7. 

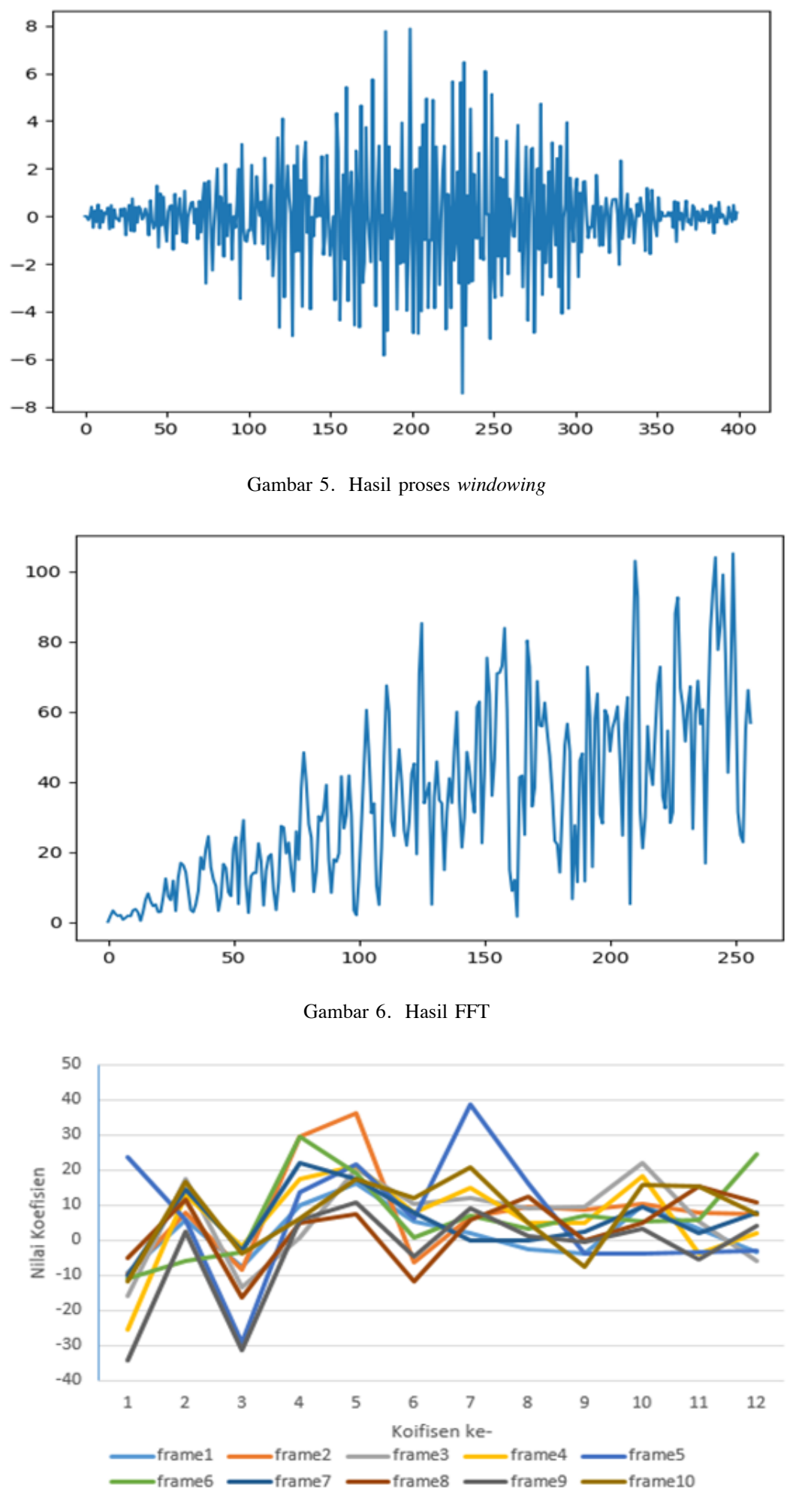

Gambar 7. Hasil ekstrasi ciri 


\section{RESUlt AND DisCUSSION}

Pada bagian ini ditunjukkan hasil pengujian yang dilakukan terkait penggunaan parameter degree $(d)$ pada kernel Polynomial, gamma $(\gamma)$ pada kernel RBF, Linier, dan Sigmoid serta penambahan noise pada data uji serta ditampilkan pelatihan dengan metode 5-fold cross validation.

\section{A. Pengaruh Parameter d (degree) pada Kernel Polynomial}

Gambar 8 menunjukkan rata-rata akurasi untuk 5-fold cross-validation. Semakin besar nilai $d$, akurasi sistem menjadi fluktuatif dan kurang stabil. Hal ini terjadi karena smakin tinggi nilai $d$ maka garis hypeplane yang dihasilkan semakin melengkung. Nilai parameter $d$ pada pengujian yang dilakukan sudah optimal pada $d=1$ dengan akurasi tertinggi sebesar 99.68\%. Tabel I mengilustrasikan secara detail nilai akurasi pada setiap fold.

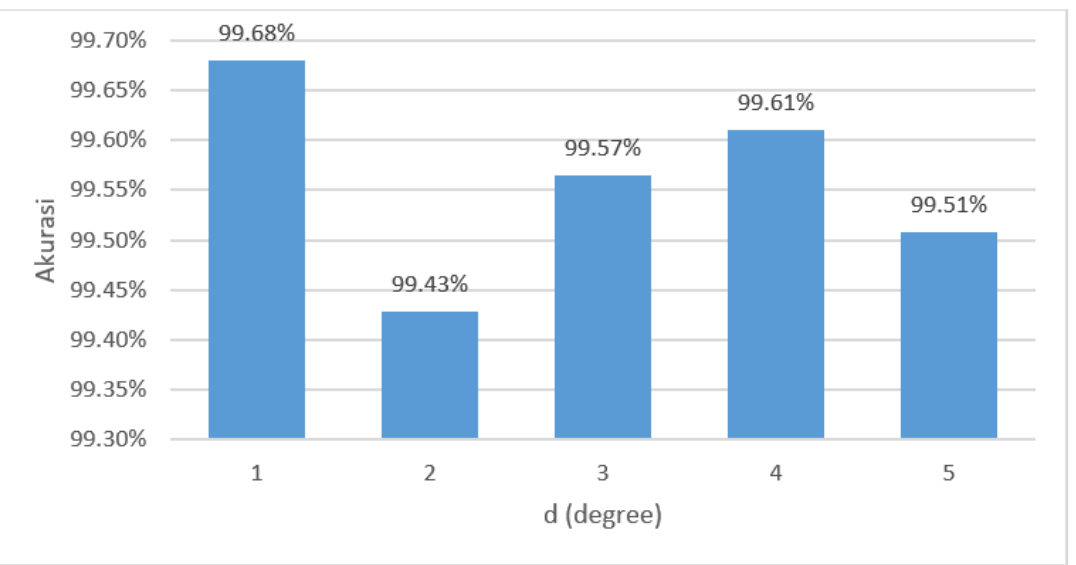

Gambar 8. Rata-rata akurasi setiap fold pada parameter $d$ kernel Polynomial

Tabel I

AKURASI DETAIL PADA SETIAP FOLD

\begin{tabular}{|c|c|c|c|c|c|c|}
\hline degree & fold1 & fold2 & fold3 & fold4 & fold5 & average \\
\hline 1 & $99.8 \%$ & $99.5 \%$ & $99.8 \%$ & $99.7 \%$ & $99.6 \%$ & $99.7 \%$ \\
\hline 2 & $99.6 \%$ & $99.2 \%$ & $99.4 \%$ & $99.7 \%$ & $99.3 \%$ & $99.4 \%$ \\
\hline 3 & $99.7 \%$ & $99.5 \%$ & $99.7 \%$ & $99.7 \%$ & $99.3 \%$ & $99.6 \%$ \\
\hline 4 & $99.7 \%$ & $99.7 \%$ & $99.7 \%$ & $99.5 \%$ & $99.4 \%$ & $99.6 \%$ \\
\hline 5 & $99.5 \%$ & $99.6 \%$ & $99.7 \%$ & $99.5 \%$ & $99.2 \%$ & $99.5 \%$ \\
\hline
\end{tabular}

\section{B. Pengaruh Parameter gamma pada Kernel RBF}

Hasil eksperimen untuk menganalisis parameter gamma pada kernel RBF diilustrasikan pada Gambar 9. Hasil ini memiliki kemiripan dengan kernel polynominal. Hal ini disebabkan semakin kecil nilai gamma, maka dua titik data yang bejarak jauh dapat dikatakan sama. Pada kernel RBF, nilai parameter optimal dihasilkan pada gamma $=0.2$ dengan akurasi $50.15 \%$. Akurasi detail pada setiap fold diilustrasikan pada Tabel II.

\section{Pengaruh kernel dalam SVM}

Berikut adalah grafik gabungan akurasi terbaik yang sudah didapat pada subbagian A dan B, ditambah dengan kernel Linier dan kernel Sigmoid. Hasil pada Gambar 10 merupakan akurasi terbaik setiap kernel dari 5-fold. Berdasarkan Gambar 10 dapat disimpulkan kernel terbaik adalah kernel Polynomial dengan $d=1$ yang menghasilkan akurasi tertinggi $99.68 \%$. 


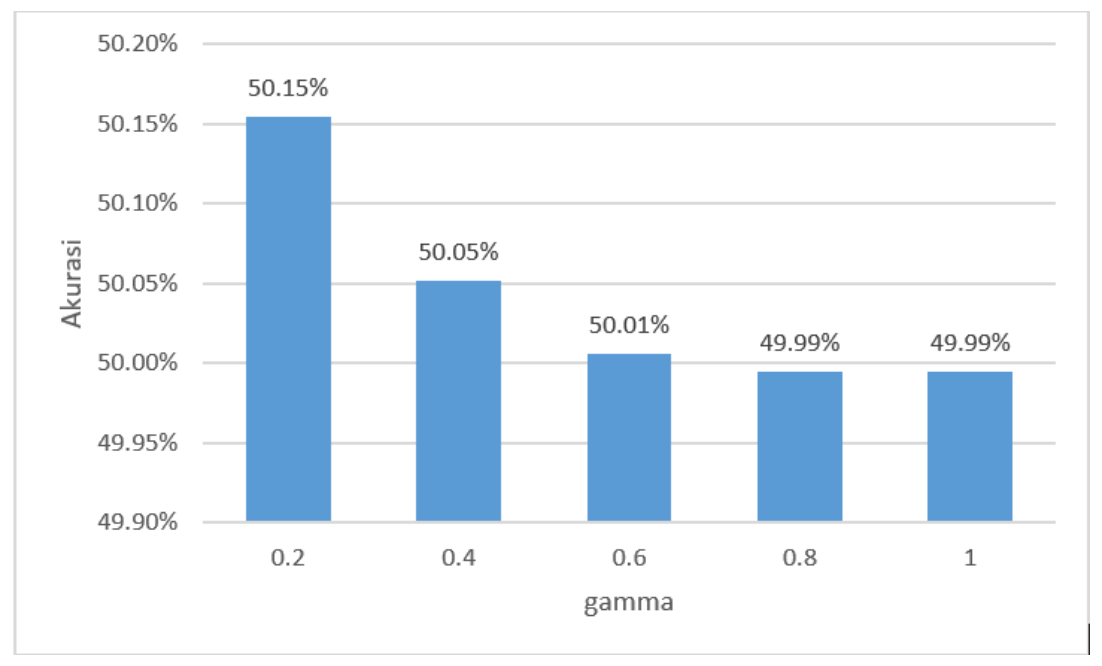

Gambar 9. Hasil rata-rata akurasi tiap $k$-fold pada parameter gamma kernel RBF

Tabel II

DETAIL AKURASI TIAP FOLD

\begin{tabular}{|c|c|c|c|c|c|c|}
\hline gamma & fold1 & fold2 & fold3 & fold4 & fold5 & average \\
\hline 0.2 & $50.00 \%$ & $50.00 \%$ & $50.00 \%$ & $50.00 \%$ & $50.77 \%$ & $50.15 \%$ \\
\hline 0.4 & $50.00 \%$ & $50.00 \%$ & $50.00 \%$ & $50.00 \%$ & $50.26 \%$ & $50.05 \%$ \\
\hline 0.6 & $50.00 \%$ & $50.00 \%$ & $50.00 \%$ & $50.00 \%$ & $50.03 \%$ & $50.01 \%$ \\
\hline 0.8 & $50.00 \%$ & $50.00 \%$ & $50.00 \%$ & $50.00 \%$ & $49.97 \%$ & $49.99 \%$ \\
\hline 1 & $50.00 \%$ & $50.00 \%$ & $50.00 \%$ & $50.00 \%$ & $49.97 \%$ & $49.99 \%$ \\
\hline
\end{tabular}

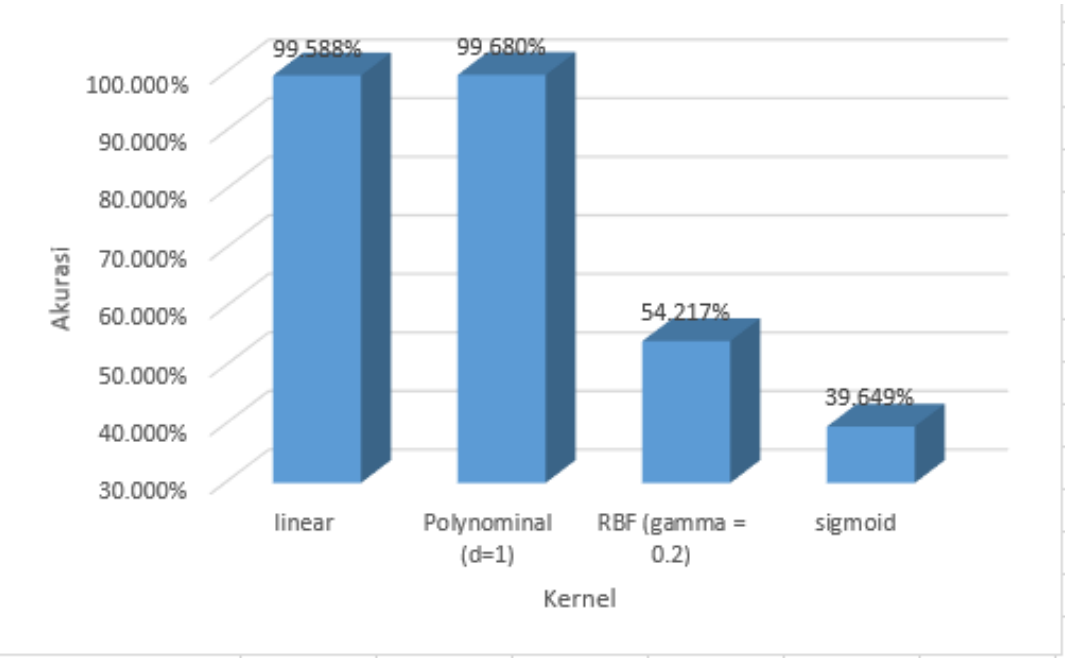

Gambar 10. Hasil akurasi pengaruh kernel pada SVM

\section{Pengujian terhadap data ber-noise}

Dataset yang berjumlah 2.260 suara dibagi menjadi dua. Pertama, 1.748 suara digunakan untuk pelatihan. Kedua, 512 suara untuk pengujian. Data latih digunakan untuk pembangunan model SVM dengan kernel Polynomial dan $d=1$. Sementara itu, semua data uji diberikan noise yang berisi rekaman suara kemacetan dalam kota dengan sejumlah tingkat derau yang berbeda-beda. Hasil pengujian pada Gambar 11 menunjukkan bahwa sistem yang dibangun mampu menghasilkan akurasi sempurna 100\% 
RADitya B. HANDOKO ET.AL.

Klasifikasi Gender Berdasarkan...

pada data tanpa noise. Namun, akurasi ini menurun sedikit menjadi 95,12\% untuk data uji yang diberi noise rendah $(-25 \mathrm{~dB})$. Akurasi menurun drastis secara cepat seiring dengan semakin besarnya noise. Ketika power sinyal $0 \mathrm{~dB}$, yang berarti suara asli dan noise sama besar, akurasi sistem hanya $66,21 \%$.

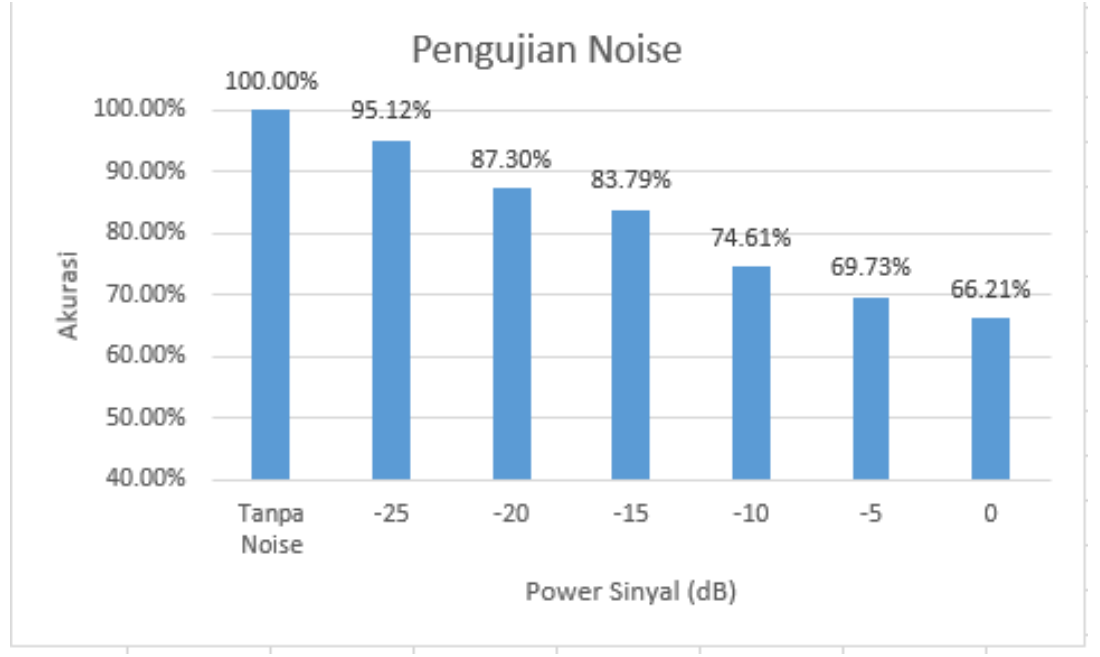

Gambar 11. Hasil akurasi data tanpa noise dan dengan noise

\section{CONCLUSION}

Sistem klasifikasi gender berdasarkan suara menggunakan SVM yang dibangun mampu memberikan akurasi sebesar 100\%. Pemilihan parameter dan kernel SVM sangat mempengaruhi akurasi sistem. Kernel RBF dan Sigmoid mempunyai akurasi lebih buruk dibanding Linear dan Polynomial $(d=1)$. Hal ini disebabkan karena dataset yang digunakan bersifat linier. Ketahanan sistem masih relatif rendah. Ketika penambahan noise cukup besar, lebih dari $-15 \mathrm{~dB}$, akurasi sistem menurun drastis. Hal ini disebabkan sistem sulit membedakan mana suara asli dan mana noise. Penelitian ini dapat dilanjutkan dengan fokus pada proses pelatihan menggunakan trainset yang sebagian telah diberikan noise sintetis yang terukur untuk menghasilkan sistem yang lebih tahan terhadap noise. 


\section{ACKNOWLEDGMENT}

Penulis mengucapkan terimakasih kepada kedua orangtua dan semua kolega di Telkom University yang telah mendukung riset ini.

\section{PUSTAKA}

[1] Jamil Ahmad, Mustansar Fiaz, Soon-il Kwon, Maleerat Sodanil, Bay Vo, and Sung Wook Baik. Gender Identification using MFCC for Telephone Applications - a Comparative Study. arXiv preprint arXiv:1601.01577, 2016.

[2] Sreedhar Bhukya. Effect of Gender on Improving Speech Recognition System. International Journal of Computer Applications, 179:22-30, 2018.

[3] Yashpalsing Chavhan. Speech Emotion Recognition Using Support Vector Machine. International Journal of Computer Applications, 1(20):6-9, 2010.

[4] Joyce de Vegte and Yin Xiaoli. Fundamentals of digital signal processing. Prentice Hall, 2002.

[5] A Ganapathiraju, J E Hamaker, and J Picone. Applications of support vector machines to speech recognition. IEEE Transactions on Signal Processing, 52(8):2348-2355, aug 2004.

[6] Sarah Ita Levitan, Taniya Mishra, and Srinivas Bangalore. Automatic identification of gender from speech. In Speech Prosody 2016, pages 84-88, 2016.

[7] Feng Lin, Yan Zhuang, Xi Long, and Wenyao Xu. Human Gender Classification : A Review. IJBM, 8(July):275-300, 2015.

[8] University McGill. The Telecommunications \& Signal Processing Laboratory, 2019.

[9] Jaume Padrell-sendra and D Fernando. Support Vector Machines for Continuous Speech Recognition. In the 14th European Signal Processing Conference (EUSIPCO), number Eusipco, pages 2-5, 2006.

[10] Kashyap Patel and R K Prasad. Speech recognition and verification using MFCC \& VQ. Int. J. Emerg. Sci. Eng.(IJESE), 1(7), 2013.

[11] Urmila Shrawankar and Vilas M Thakare. Techniques for feature extraction in speech recognition system: A comparative study. arXiv preprint arXiv:1305.1145, 2013. 
